\section{TRENDS IN INTERNATIONAL ARMS TRANSFERS, 2014}

\author{
PIETER D. WEZEMAN AND SIEMON T. WEZEMAN
}

The volume of international transfers of major weapons in 2010-14 was 16 per cent higher than in 2005-2009 (see figure 1). The five biggest exporters in 2010-14 were the United States, Russia, China, Germany and France, and the five biggest importers were India, Saudi Arabia, China, the United Arab Emirates (UAE) and Pakistan.

The flow of arms to Africa, the Americas, Asia and Oceania, and the Middle East increased significantly between 2005-2009 and 2010-14, while there was a notable decrease in the flow to Europe.

From 16 March 2015 the SIPRI Arms Transfers Database (see box 1) includes newly released information on arms transfers during 2014 and updated information for 1950-2013. This Fact Sheet highlights key trends and issues in arms transfers that are revealed by the new data. It lists the main exporters and importers in 2010-14 and describes the regional trends. Since the volume of deliveries of arms can fluctuate significantly from one year to the next, SIPRI uses a five-year moving average to give a more stable measure of trends in transfers of major weapons. Figures do not always add up to totals because of the conventions of rounding.

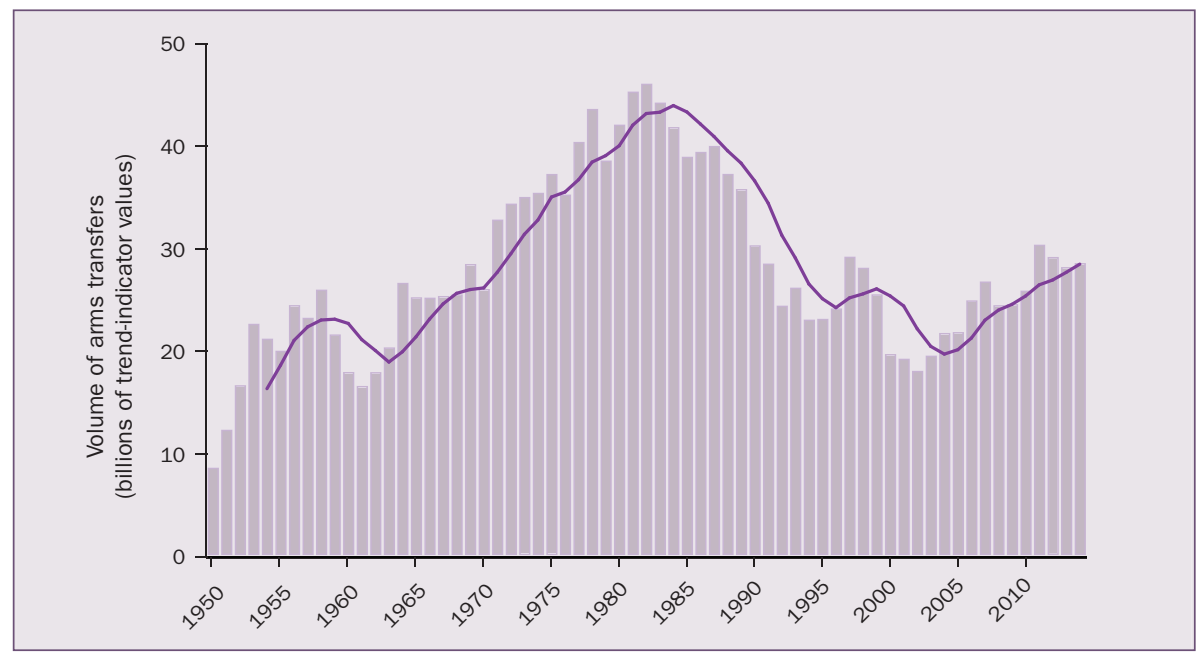

Figure 1. The trend in international transfers of major weapons, 1950-2014

Note: The bar graph shows annual totals and the line graph shows the 5-year moving average (each data point in the line graph represents an average for the preceding 5-year period). The SIPRI trend-indicator value (TIV) is a measure of the volume of international transfers of major weapons. The method used to calculate the SIPRI TIV is described on the SIPRI website at <http://www.sipri.org/research/armaments/ transfers/measuring>.

\section{KEY FACTS}

- The volume of transfers of major weapons in 2010-14 was 16 per cent higher than in $2005-$ 2009.

- The five biggest exporters in 2010-14 were the USA, Russia, China, Germany and France. Together, they accounted for 74 per cent of the volume of arms exports. Combined, the USA and Russia supplied 58 per cent of all exports.

- China replaced Germany as the third largest arms exporter in 2010-14; in 2005-2009 it ranked ninth.

- Total exports from all EU member states in 2010-14 were 16 per cent lower than in 2005-2009; in 2005-2009 EU export volumes were higher than those for the USA or Russia, while in 2010-14 they were below US and Russian export totals.

- The five biggest importers in 2010-14 were India, Saudi Arabia, China, the UAE and Pakistan. Together, they received 33 per cent of all arms imports.

- The main recipient region in 2010-14 was Asia and Oceania (accounting for 48 per cent of imports), followed by the Middle East (22 per cent), Europe (12 per cent), the Americas (10 per cent) and Africa (9 per cent).

- Between 2005-2009 and 2010-14, arms imports by states in Africa increased by 45 per cent, Asia and Oceania by 37 per cent, the Middle East by 25 per cent and the Americas by 7 per cent. Imports by states in Europe decreased by 36 per cent. 
Box 1. The SIPRI Arms Transfers Database

The SIPRI Arms Transfers Database contains information on all international transfers of major weapons (including sales, gifts and production under licence) to states, international organizations and armed non-state groups since 1950. It is the only publicly available resource providing consistent data on arms transfers for this length of time.

The database can be used to track transfers of major weapons and to answer such questions as:

- Who are the main suppliers and recipients of major weapons?

- How have relations between different suppliers and recipients changed over time?

- Where do countries in conflict get their weapons?

- How do states implement their export control regulations?

- Where are potentially destabilizing build-ups of weapons occurring today?

- What major weapons have been exported or imported?

The database is available online at <http://www.sipri.org/databases/arms transfers/>.

\section{THE EXPORTERS, 2010-14}

SIPRI has identified 60 countries as exporters of major weapons in 2010-14. The top 5 exporters during the period-the USA, Russia, China, Germany and France-were responsible for almost 74 per cent of all arms exports (see table 1). The composition of the five largest exporters of arms changed between 2005-2009 and 2010-14: while the USA and Russia remained by far the largest exporters, China narrowly, but notably, replaced Germany as the third largest exporter, and the United Kingdom dropped outside the top 5 . The top 5 exported 14 per cent more arms in 2010-14 than the top 5 in 2005-2009.

\section{The United States}

US exports of major weapons increased by 23 per cent between 2005-2009 and 2010-14 (see figure 2). More than any other supplier, the USA delivered major weapons to at least 94 recipients in 2010-14, and no single recipient accounted for more than 9 per cent of total US weapon exports. Asia and Oceania was the biggest recipient region of US weapons, accounting for 48 per cent. The Middle East received 32 per cent and Europe 11 per cent.

Table 1. The 10 largest exporters of major weapons and their main clients, 2010-14

\begin{tabular}{|c|c|c|c|c|c|}
\hline \multirow[b]{2}{*}{ Exporter } & \multicolumn{2}{|c|}{$\begin{array}{l}\text { Share of international } \\
\text { arms exports (\%) }\end{array}$} & \multicolumn{3}{|c|}{$\begin{array}{l}\text { Main clients (share of exporter's total exports), } \\
2010-14\end{array}$} \\
\hline & 2010-14 & 2005-2009 & 1 st & 2nd & $3 \mathrm{rd}$ \\
\hline USA & 31 & 29 & South Korea (9\%) & UAE (8\%) & Australia (8\%) \\
\hline Russia & 27 & 22 & India (39\%) & China (11\%) & Algeria (8\%) \\
\hline China & 5 & 3 & Pakistan (41\%) & Bangladesh (16\%) & Myanmar (12\%) \\
\hline Germany & 5 & 11 & USA (11\%) & Israel (9\%) & Greece (7\%) \\
\hline France & 5 & 8 & Morocco (18\%) & China (14\%) & UAE (8\%) \\
\hline UK & 4 & 4 & Saudi Arabia (41\%) & USA (12\%) & India (11\%) \\
\hline Spain & 3 & 3 & Australia (24\%) & Norway (10\%) & Saudi Arabia (10\%) \\
\hline Italy & 3 & 2 & UAE (9\%) & India (9\%) & Turkey (8\%) \\
\hline Ukraine & 3 & 2 & China (22\%) & Russia (10\%) & Thailand (9\%) \\
\hline Israel & 2 & 2 & India (46\%) & Colombia (7\%) & Singapore (6\%) \\
\hline
\end{tabular}

\section{Russia}

Russian exports of major weapons increased by 37 per cent between 2005-2009 and 2010-14. Russia delivered weapons to 56 states and to rebel forces in eastern Ukraine in 2010-14. In contrast to the USA, Russia's deliveries were more concentrated: three countries-India, China and Algeria-accounted for almost 60 per cent of total

Russian exports. Asia and Oceania received 66 per cent of Russian arms exports in 2010-14, Africa 12 per cent and the Middle East 10 per cent. 


\section{China}

Chinese exports of major arms increased by 143 per cent between 2005-2009 and 2010-14, and China's share of global arms exports increased from 3 to 5 per cent. China became the third largest supplier in 2010-14, slightly ahead of Germany and France. China supplied major arms to 35 states in 2010-14. A significant percentage (just over 68 per cent) of Chinese exports went to three countries: Pakistan, Bangladesh and Myanmar. China also exported major arms to 18 African states. Examples of China's increasing global presence as an arms supplier in 2010-14 included deals with Venezuela for armoured vehicles and transport and trainer aircraft, with Algeria for three frigates, with Indonesia for the supply of hundreds of anti-ship missiles and with Nigeria for the supply of a number of unmanned combat aerial vehicles (see box 2).

\section{Germany}

Germany's exports of major weapons decreased by 43 per cent between 20052009 and 2010-14. Germany supplied major arms to 55 states. Other states in Europe received 30 per cent of German arms exports in 2010-14, followed by Asia and Oceania (26 per cent), the Americas (24 per cent) and the Middle East (20 per cent).

In 2014 the new German Government announced a more restrictive arms export policy, particularly in response to discussions about arms exports to the Middle East. However, notable orders in 2014 included 33 patrol boats for Saudi Arabia, 4 frigates for Israel, 2 Type-209 submarines for Egypt and 926 armoured personnel carriers (APCs) for Algeria.

\section{France}

France was the fifth largest weapons exporter in 2010-14, with exports 27 per cent lower than in 2005-2009. It exported arms to 74 countries in 2010-14: 29 per cent went to states in Asia and Oceania,

\section{Box 2. Transfers of unmanned aerial vehicles}

The transfer of unmanned aerial vehicles (UAVs or drones) is not new; the first transfers took place around 1970. However, the number of exporters, importers and UAVs transferred has grown significantly over the past 15 years. In 2010-14 at least 35 countries and the United Nations together received 429 larger UAVs (counting those with a take-off weight of 25 kilograms or more). The deliveries vary from $25-\mathrm{kg}$ UAVs with a short range to 15 000-kg UAVs with a near global range (e.g. Global Hawk). Israel and the United States have been the main suppliers, but exports have also been recorded from Austria, China, France, Germany, Iran, Italy, South Africa and Sweden. With very few exceptions these are unarmed UAVs for reconnaissance purposes.

While the USA has used armed UAVs (also called unmanned combat aerial vehicles, UCAVs) intensively for the past decade and other countries have expressed widespread interest in their acquisition, UCAVs have been sold only to the United Kingdom and Nigeria. Between 2007 and 2014 the UK received 11 MQ-9 Reaper UCAVs from the USA and has used them in operations in Afghanistan. Nigeria received (probably in 2014) an unidentified number of CH-3 UCAVs from China and has used them against Boko Haram rebels. However, for combat, including against rebel forces, states still rely on manned combat aircraft (armed with a growing array of guided weapons), long-range artillery and ground-to-ground missiles. 
21 per cent to Africa, 20 per cent to the Middle East, 16 per cent to other states in Europe and 14 per cent to the Americas. In 2014 France halted the planned delivery of one amphibious assault ship to Russia due to the latter's involvement in the Ukraine crisis. If the deal had gone ahead, France would have been the third largest arms exporter in 2010-14 ahead of China and Germany. French efforts to increase arms exports were boosted by a deal negotiated in 2014 and signed in early 2015 with Egypt for the delivery of 24 combat aircraft and 1 frigate.

\section{THE IMPORTERS, 2010-14}

In 2010-14, 153 countries (about three-quarters of all countries) imported major weapons. The top 5 recipients-India, Saudi Arabia, China, the UAE and Pakistan-accounted for 33 per cent of the total arms imports during the period (see table 2). India, China and the UAE were among the top 5 importers in both 2005-2009 and 2010-14. Asia and Oceania accounted for nearly half of imports in 2010-14, followed by the Middle East, Europe, the Americas and Africa (see figure 3). SIPRI also identified seven groups of rebel forces as importers of major weapons in 2010-14, but none of them accounted for more than 0.02 per cent of total deliveries.

Table 2. The 10 largest importers of major weapons and their main suppliers, 2010-14

\begin{tabular}{|c|c|c|c|c|c|}
\hline \multirow[b]{2}{*}{ Importer } & \multicolumn{2}{|c|}{$\begin{array}{l}\text { Share of international } \\
\text { arms imports (\%) }\end{array}$} & \multicolumn{3}{|c|}{$\begin{array}{l}\text { Main suppliers (share of importer's total imports), } \\
2010-14\end{array}$} \\
\hline & 2010-14 & 2005-2009 & 1 st & $2 \mathrm{nd}$ & $3 \mathrm{rd}$ \\
\hline India & 15 & 7 & Russia (70\%) & USA (12\%) & Israel (7\%) \\
\hline Saudi Arabia & 5 & 1 & UK (36\%) & USA (35\%) & France (6\%) \\
\hline China & 5 & 9 & Russia (61\%) & France (16\%) & Ukraine (13\%) \\
\hline UAE & 4 & 5 & USA (58\%) & France (9\%) & Russia (9\%) \\
\hline Pakistan & 4 & 3 & China (51\%) & USA (30\%) & Sweden (5\%) \\
\hline Australia & 4 & 3 & USA (68\%) & Spain (19\%) & France (6\%) \\
\hline Turkey & 3 & 3 & USA (58\%) & South Korea (13\%) & Spain (8\%) \\
\hline USA & 3 & 3 & Germany (18\%) & UK (15\%) & Canada (13\%) \\
\hline South Korea & 3 & 6 & USA (89\%) & Germany (5\%) & Sweden (2\%) \\
\hline Singapore & 3 & 3 & USA (71\%) & Germany (10\%) & Sweden (6\%) \\
\hline
\end{tabular}

largest importer in the subregion, accounting for, respectively, 15 per cent and 14 per cent of the subregional total.

\section{Algeria and Morocco}

Between 2005-2009 and 2010-14 imports by Algeria increased by 3 per cent; imports by its regional rival Morocco increased elevenfold. In 2014, major deliveries to Algeria included 1 helicopter carrier from Italy, the last batch of 48 air defence systems from Russia and an estimated 50 selfpropelled guns from China; meanwhile, Morocco received 1 frigate from France. Algeria, unlike Morocco, has several major outstanding arms orders. These include orders placed in 2014 for 2 submarines and 42 combat helicopters from Russia and 926 APCs from Germany. The orders for helicopters 
and APCs appear partly related to the Algerian Government's conflict with rebel groups.

\section{Nigeria and Cameroon fighting Boko Haram}

Nigeria and Cameroon received weapons from several suppliers to fulfil their urgent demand for weapons to fight against the militant Islamist group Boko Haram. Taken together, in 2014, both countries ordered and received helicopters from China and Russia, and armoured vehicles from China, Czech Republic, South Africa and Ukraine. Canadian companies also supplied armoured vehicles from production lines based in Nigeria and the UAE.

\section{The Americas}

Imports of major weapons by states in the Americas increased by 7 per cent between 2005-2009 and 2010-14. The USA was the largest importer of major weapons in the Americas in 2010-14. Venezuela was the second largest importer in the Americas and the largest importer in South America. Brazil was the third largest importer in the Americas and had by far the largest amount of outstanding orders of all South American states.

\section{The United States}

Despite the fact that most major US arms acquisitions involve indigenous designs, the USA was the world's eighth largest importer of major weapons in 2010-14. US arms imports increased by 21 per cent between 2005-2009 and 2010-14.

Aircraft accounted for 44 per cent of US imports in 2010-14. The main imports were 19 transport aircraft from Italy and US-produced weapons under licence, including 252 trainer aircraft of Swiss design, 223 light helicopters of German design and 10 maritime patrol aircraft of Spanish design.

\section{Asia and Oceania}

Arms imports by states in Asia and Oceania increased by 37 per cent between 2005-2009 and 2010-14. States in the region received 48 per cent of all imports in 2010-14, up from 40 per cent in 2005-2009. States in South Asia accounted for 46 per cent of the regional total, North East Asia for 23 per cent, South East Asia for 22 per cent, Oceania for 8 per cent and Central Asia for 1 per cent. Of the 10 largest importers in 2010-14, 6 were in Asia and Oceania: India, China, Pakistan, Australia, South Korea and Singapore.

India

India was the largest importer of major arms in 2010-14, accounting for 15 per cent of the global total. Between 2005-2009 and 2010-14 imports increased by 140 per cent. In 2010-14 India's imports were three times larger
2010-2014

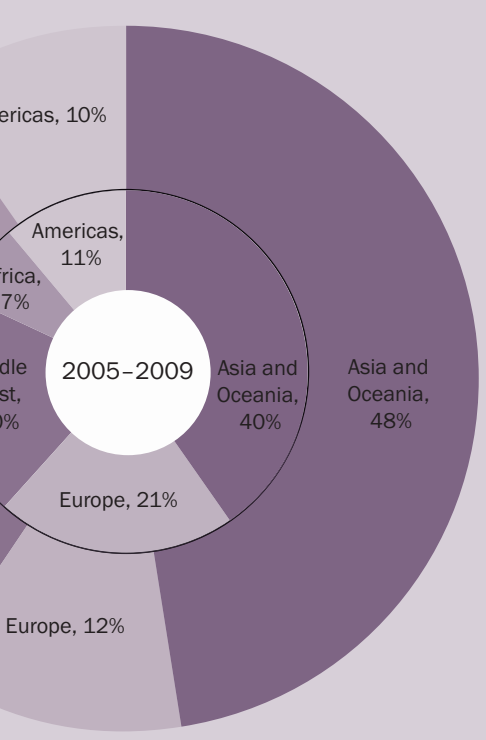

Figure 3. The importers of major weapons, by region, 2005-2009 and 2010-14, per cent of global share 


\section{Box 3. Combat aircraft procurement in South East Asia and Oceania}

Many states in South East Asia significantly modernized and expanded their fleets of combat aircraft in 2010-2014. Several also ordered tanker aircraft that significantly expand the reach of combat aircraft. Singapore received 32 F-15E combat aircraft from the United States in 2010-14 and in 2014 ordered 6 A330 tanker aircraft from Spain. Singapore is also a minor partner in the USA's F-35A combat aircraft programme and is expected to place an order in the near future. Russia delivered $24 \mathrm{Su}-30$ aircraft to Viet $\mathrm{Nam}$ and 8 more are on order. Indonesia received $3 \mathrm{Su}-27$ and $6 \mathrm{Su}-30$ aircraft from Russia and the first 5 of 24 F-16C aircraft from the USA. It also received 16 T-50 light combat aircraft from South Korea. Indonesia has placed an order for $50 \mathrm{KFX}$ combat aircraft from South Korea and has plans to procure a large number of new combat and tanker aircraft. The Philippines ordered 12 FA-50 combat aircraft from South Korea in 2014 (its first order for advanced combat aircraft in decades) and plans to order a further 24 combat aircraft. Thailand received 12 Gripen-C combat aircraft from Sweden. Malaysia is looking at several potential suppliers for a planned order of 18 new combat aircraft and has 4 A400M tanker/transport aircraft on order from Spain.

Australia acquired a number of new combat aircraft during 2014. The USA delivered $24 \mathrm{~F} / \mathrm{A}-18 \mathrm{E}$ and $2 \mathrm{~F}-35 \mathrm{~A}$ combat aircraft. Australia is only the third export customer of the F-35A to have actually received the aircraft. Another $70 \mathrm{~F}-35 \mathrm{~A}$ and 12 EA-18G combat aircraft are on order. than those of either of its regional rivals China and Pakistan. This contrasts with 2005-2009 when India's imports were 23 per cent below China's and just over double those of Pakistan. India has so far failed to produce competitive indigenous-designed weapons and remains dependent on imports.

In 2010-14 Russia supplied 70 per cent of India's arms imports, the USA 12 per cent and Israel 7 per cent. The acquisitions from the USA are a break with the recent past. Prior to 2005-2009 India barely received any major weapons from the USA. However, there now appears to be an upward trend in arms imports from the USA. Imports in 2010-14 were 15 times higher than in 2005-2009 and included advanced weapons such as anti-submarine warfare aircraft. In 2014 additional deals with the USA were agreed, including for 22 combat helicopters.

\section{China}

Following rapid advances in its arms industry, China has become less dependent on arms imports, which decreased by 42 per cent between 2005-2009 and 2010-14. It dropped from being by far the largest importer in 2005-2009-over 30 per cent larger than the second largest, India-to third place. Russia accounted for 61 per cent of Chinese arms imports, followed by France with 16 per cent and Ukraine with 13 per cent.

Helicopters formed a major part of Russian and French deliveries, with the French designs produced under licence in China. Over the years, China has struggled to design and produce effective engines for combat and transport vehicles. It continued to import large numbers of engines from Russia and Ukraine in 2010-14 for indigenously designed combat, advanced trainer and transport aircraft, and for naval ships. It also produced British-, French- and German-designed engines for combat aircraft, naval ships and armoured vehicles, mostly as part of agreements that have been in place for decades.

\section{Australia}

Australia's imports of major weapons increased 65 per cent between 20052009 and 2010-14, making it the sixth largest importer in the world. The USA supplied 68 per cent of Australia's imports and Spain 19 per cent.

Australia is modernizing its armed forces but also acquiring weapons that significantly increase its long-range capabilities. Among the weapons imported in 2010-14 were 5 tanker aircraft and the first of 2 amphibious assault ships from Spain, along with 2 large transport aircraft and 4 air- 
borne early warning (AEW) aircraft from the USA. Australia also received 26 combat aircraft from the USA, with 82 more on order (see box 3), as well as 8 anti-submarine warfare aircraft from the USA and 3 Hobart destroyers from Spain.

\section{Europe}

Imports by states in Europe decreased by 36 per cent between 2005-2009 and 2010-14. The UK was the largest importer of major weapons in Europe (receiving 14 per cent of deliveries), followed by Azerbaijan (13 per cent).

\section{The United Kingdom}

British arms imports exemplify how such imports are crucial to military operations in several regions around the world in which many European countries are involved. For example, in 2014 the UK operated its first RC-135 signal intelligence aircraft, delivered from the USA in 2013, in operations against the Islamic State of Iraq and al-Sham (ISIS), and ordered 20 submarine-launched cruise missiles from the USA to replace missiles used in recent military actions.

\section{Azerbaijan, Armenia and Nagorno-Karabakh}

Azerbaijan-which has a territorial dispute with Armenia over the NagornoKarabakh region that saw rising tensions in 2014-increased its arms imports by 249 per cent between 2005-2009 and 2010-14. Russia accounted for 85 per cent of Azerbaijan's arms imports. Armenia's imports were just 4 per cent of those of Azerbaijan. The de facto armed forces of Nagorno-Karabakh are substantial, but it remains unclear when and from where those forces have acquired their weapons. However, it is highly likely that Armenia has supplied at least some of the weapons.

\section{European reactions to Russia}

Russia's foreign policy and the rebuilding of Russian armed forces have been viewed with apprehension by other European states. However, these developments had only minor effects on arms procurement in 2014. Several states bordering Russia imported or ordered new equipment in 2014 to strengthen their defences as part of more expansive military modernization plans already in place: Poland received most of the 119 tanks on order from Germany, and it ordered 40 cruise missiles from the USA and 120 self-propelled guns from South Korea; Estonia ordered 44 second-hand armoured vehicles from the Netherlands; and Latvia ordered 123 second-hand armoured vehicles from the UK.

\section{The Middle East}

Arms imports by states in the Middle Eastincreased by 25 per cent between

Box 4. Acquisitions of ballistic missile defence systems

The first international transfers of ballistic missile defence systems took place between 2000 and 2009. During that period, the United States supplied SM-3 Block1A ship-based anti-ballistic missiles to Japan and Patriot PAC-3 systems to Germany, Japan and the Netherlands. In 2010-2014 the number of states that imported such systems rapidly increased. Kuwait, Qatar, Saudi Arabia and the United Arab Emirates (UAE) received or ordered Patriot PAC-3 systems from the USA, presumably in response to a perceived missile threat from Iran. The UAE also ordered the more advanced Terminal High Altitude Defense (THAAD) system from the USA. In East Asia, Taiwan received three of the nine Patriot PAC-3 systems ordered and in 2014 South Korea decided to procure eight of the same system. 
SIPRI is an independent international institute dedicated to research into conflict, armaments, arms control and disarmament. Established in 1966, SIPRI provides data, analysis and recommendations, based on open sources, to policymakers, researchers, media and the interested public.

\section{GOVERNING BOARD}

Sven-Olof Petersson, Chairman (Sweden)

Dr Dewi Fortuna Anwar

(Indonesia)

Dr Vladimir Baranovsky (Russia)

Ambassador Lakhdar Brahimi (Algeria)

Jayantha Dhanapala (Sri Lanka)

Ambassador Wolfgang Ischinger (Germany)

Professor Mary Kaldor (United Kingdom)

The Director

\section{DIRECTOR}

Dr Ian Anthony (United Kingdom)

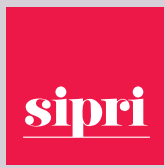

STOCKHOLM INTERNATIONAL PEACE RESEARCH INSTITUTE Signalistgatan 9 SE-169 70 Solna, Sweden Telephone: +4686559700 Fax: +4686559733

Email:sipri@sipri.org Internet: www.sipri.org
2005-2009 and 2010-14. During 2010-14, 23 per cent of arms transfers to the region went to Saudi Arabia, 20 per cent to the UAE and 16 per cent to Turkey. The USA accounted for 47 per cent of total arms supplies to the region, Russia for 12 per cent and the UK for 10 per cent. Several countries in the region are heavily investing in ballistic missile defence systems (see box 4) and air defence systems.

\section{Saudi Arabia and Qatar}

In 2010-14 Saudi Arabia became the world's second largest arms importer, receiving four times more major arms than in 2005-2009. Major imports in 2010-14 included 45 combat aircraft from the UK, 38 combat helicopters from the USA, 4 tanker aircraft from Spain and over 600 armoured vehicles from Canada. Saudi Arabia has a long list of outstanding orders for arms, including 27 more combat aircraft from the UK, 154 combat aircraft from the USA and a large number of armoured vehicles from Canada.

In 2010-14 Qatar was the 46th largest arms importer in the world. However, its plans to transform and significantly enlarge its armed forces have accelerated. Orders in 2013 for 62 tanks and 24 self-propelled guns from Germany were followed in 2014 by a number of other contracts, including 24 combat helicopters and 3 AEW aircraft from the USA, and 2 tanker aircraft from Spain.

\section{Arms exports to countries in internal conflict}

In response to the Egyptian military coup in 2013, the USA had restrained its arms exports to Egypt. However, in 2014 the USA restarted deliveries of some major weapons. The most notable delivery was for 10 combat helicopters, which were considered of particular importance in the support of Egypt's military campaign against rebels in the Sinai.

In 2014, imports of major arms by Syria appeared to have reduced significantly. The planned delivery of MiG-29 and Yak-130 combat aircraft ordered from Russia was postponed again.

From 2003 to 2013 Iraq imported large volumes of less-advanced major weapons from a variety of suppliers, including over 10000 armoured vehicles from the USA. Despite the large influx of weapons, ISIS forces were able to defeat Iraqi government forces on a number of occasions in 2014 and to capture Iraqi arms. In response to ISIS advances in 2014, many countries sent emergency military aid, including numerous second-hand weapons such as the first of 250 armoured personnel carriers from the USA, 18 towed guns from Bulgaria, 500 guided anti-tank missiles from Germany and 7 combat aircraft from Iran. Russia also became a significant supplier to Iraq, delivering the first 15 of 43 combat helicopters during 2013-14 and 5 combat aircraft in 2014.

\section{ABOUT THE AUTHORS}

Pieter D. Wezeman (Netherlands/Sweden) and Siemon T. Wezeman (Netherlands) are Senior Researchers with the SIPRI Arms and Military Expenditure Programme. 